\title{
The Gibbs free energy of formation of halogenated benzenes, benzoates and phenols and their potential role as electron acceptors in anaerobic environments
}

\author{
Jan Dolfing • Igor Novak
}

Received: 9 April 2014/Accepted: 25 August 2014/Published online: 18 September 2014

(C) The Author(s) 2014. This article is published with open access at Springerlink.com

\begin{abstract}
The sequence of redox reactions in the natural environment generally follows the electron affinity of the electron acceptors present and can be rationalized by the redox potentials of the appropriate half-reactions. Answering the question how halogenated aromatics fit into this sequence requires information on their Gibbs free energy of formation values. In 1992 Gibbs free energy data for various classes of halogenated aromatic compounds were systematically explored for the first time based on Benson's group contribution method. Since then more accurate quantum chemical calculation methods have become available. Here we use these methods to estimate enthalpy and Gibbs free energy of formation values of all chlorinated and brominated phenols. These data and similar state-of-the-art datasets for halogenated benzenes and benzoates were then used to calculate two-electron redox potentials of halogenated aromatics for standard conditions and for $\mathrm{pH}$ 7. The results
\end{abstract}

Electronic supplementary material The online version of this article (doi:10.1007/s10532-014-9710-5) contains supplementary material, which is available to authorized users.

J. Dolfing (ه)

School of Civil Engineering and Geosciences, Newcastle University, Newcastle NE1 7RU, England, UK

e-mail: jan.dolfing@ncl.ac.uk

I. Novak

Faculty of Science, Charles Sturt University, Orange,

NSW 2800, Australia underline the need to take speciation into consideration when evaluating redox potentials at $\mathrm{pH} 7$ and highlight the fact that halogenated aromatics are excellent electron acceptors in aqueous environments.

Keywords Chlorophenol - Bromophenol ·

Dehalogenation - Redox potential $\cdot$ Chlorobenzoate

Chlorobenzene

\section{Introduction}

The seminal observations by Tiedje and co-workers on microbial dehalogenation have profoundly altered our perception of biodegradability of halogenated compounds (Suflita et al. 1982). We now know that anaerobic bacteria reductively dehalogenate a wide variety of organohalogens in a process called organohalide respiration, where organohalogens are used as electron acceptor by bacteria harnessing part of the energy released in the form of ATP (McCarty 1997; Farai et al. 2010; Leys et al. 2013). Based on this information treatment processes have been developed for the biodegradation of various classes of organohalogens including halophenols (Field and SierraAlvarez 2008). Insight in the microbial and thermodynamic logic behind the sequence of dehalogenation steps observed in these degradation processes (Dolfing 2003) requires an internally consistent set of data on the standard aqueous phase Gibbs free energy of formation 
$\left(\Delta G_{\mathrm{f}}^{\mathrm{o}}\right)$ and enthalpy of formation $\left(\Delta H_{\mathrm{f}}^{\mathrm{o}}\right)$ values for all congeners. For chlorophenols such a data set is currently not available. A previous set of data for chlorinated phenols (Dolfing and Harrison 1992) lacked values for $\Delta H_{\mathrm{f}}^{\mathrm{o}}$, thus precluding its use at temperatures other than $298.15 \mathrm{~K}$. Also, with the advent of accurate quantum chemical calculation methods and readily available computer power it is now possible to generate data sets that are more accurate than those generated 20 years ago. The objectives of the present paper are therefore (i) to present a state-of-the-art data set of $\Delta G_{\mathrm{f}}^{\mathrm{o}}$ and $\Delta H_{\mathrm{f}}^{\mathrm{o}}$ values for chlorinated phenols, and (ii) to do the same for brominated phenols. Speciation of halogenated phenols is $\mathrm{pH}$ dependent, and potentially affects the energetics of the dehalogenation reactions (Dolfing et al. 2010). Thus, our third objective is to outline the effect of $\mathrm{pH}$ on the change in Gibbs free energy for the reductive dehalogenation of halogenated phenols and on the redox potentials for the corresponding redox couples. In recent years Tang et al. (2010) and Sadowsky et al. (2013) have updated the existing database of thermochemical properties for halogenated aromatics with state-of-the-art quantum chemical information on chlorobenzoates and halobenzenes. The fourth objective of the present paper is to integrate these data into a consistent set of redox potentials for various classes of halogenated aromatics.

There is currently considerable interest in the use of microbial fuel cells for waste treatment, including waste containing halogenated phenols (Strycharz et al. 2010; Huang et al. 2012, 2014). Rational design and implementation of such systems hinges on precise knowledge of the amount of energy present in the waste (Heidrich et al. 2011). In addition to providing data for the prediction and rationalization of degradation pathways of various classes of halogenated aromatics in anaerobic environments (Dolfing 2003) the data presented here will allow a thermodynamic evaluation of the fraction of energy that is stored in the carbon-halogen bond of halogenated benzenes, benzoates and phenols.

\section{Materials and methods}

Computational methods

$\mathrm{Ab}$ initio quantum chemical calculations to estimate $\Delta H_{\mathrm{f}}^{\mathrm{o}}$ and $\mathrm{S}^{\mathrm{o}}$ values of phenol and all chlorinated and brominated phenol congeners were performed with the Gaussian 03 software, Revision E1 (Frisch et al. 2003). The use of this software for thermochemical calculations is well established (Novak 2004). The composite G3(MP2)/B3LYP method was used for calculation of total energies; the method (Baboul et al. 1999) has typical precision of $4 \mathrm{~kJ} / \mathrm{mol}$. The G3(MP2)/B3LYP method yields $\Delta G_{\mathrm{f}}^{\mathrm{o}}$ and $\Delta H_{\mathrm{f}}^{\mathrm{o}}$ values for the gas phase. For environmental applications data for the aqueous phase are generally more relevant. We therefore used the universal solvation model (Marenich et al. 2009) and G3(MP2)/B3LYP method to simulate water solvent as implemented in the Gaussian software to calculate $\Delta G_{\mathrm{f}}^{\mathrm{o}}$ and $\Delta H_{\mathrm{f}}^{\mathrm{o}}$ values for the aqueous solution.

Gibbs free energy values

The standard molar Gibbs free energy of formation $\Delta G \mathrm{f}_{\mathrm{m}}^{o}$ was calculated from the equation $\Delta G_{\mathrm{f}}^{o}=$ $\Delta H_{\mathrm{f}}^{o}-T\left[S^{o}-\Sigma\left(v_{i} S_{i}^{o}\right)\right]$ where $\Delta H_{\mathrm{f}}^{o}$ is the standard enthalpy of formation at 1 bar $(100 \mathrm{kPa}), T$ is the temperature of interest $(298.15 \mathrm{~K}), S^{o}$ is the absolute standard entropy, $v_{i}$ is the stoichiometric coefficient of element $I$, and $S_{i}^{o}$ is the absolute entropy of element $I$ in its standard reference state. $S_{i}^{o}$ values used for carbon, hydrogen, oxygen, bromine and chlorine were 5.74, $65.34,102.58,76.11$ and 111.54 J.K ${ }^{-1} \mathrm{~mol}^{-1}$ respectively (Cox et al. 1989). We have also calculated the appropriate total energies $H^{m o l}, H^{a t}, G^{m o l}, G^{a t}$ in the water solvent which allowed us to deduce the solvation energy correction for gas phase data and thus convert $\Delta H_{\mathrm{f}}^{o}(\mathrm{~g})$ and $\Delta G_{\mathrm{f}}^{o}{ }^{o}(\mathrm{~g})$ values to $\Delta H_{\mathrm{f}}^{o}(\mathrm{l})$ and $\Delta G_{\mathrm{f}}^{o}(\mathrm{l})$. The exact expressions for $H^{m o l}, H^{a t}, G^{m o l}, G^{a t}$ are given in Gaussian G03 manual (Frisch et al. 2003).

The amount of free energy available from a reaction is given by the relationship $\Delta G^{\mathrm{o}}=$ $\Sigma \Delta G_{\mathrm{f}}^{o}$ (products) $-\Sigma \Delta G_{\mathrm{f}}^{o}$ (reactants) (Thauer et al. 1977). In aqueous solutions the standard state of all solutes is $1 \mathrm{~mol} / \mathrm{kg}$ activity, that of water is the pure liquid. Under environmentally relevant conditions the concentrations of reactants and products are not $1 \mathrm{~mol} / \mathrm{kg}$. This is considered in $\Delta G^{\prime}$ values. For a hypothetical reaction $a \mathrm{~A}+b \mathrm{~B} \rightarrow c \mathrm{C}+d \mathrm{D}, \Delta G^{\prime}$ values are calculated by using the mass equation

$\Delta G^{\prime}=\Delta G^{o \prime}+R T \ln [\mathrm{C}]^{c}[\mathrm{D}]^{d} /[\mathrm{A}]^{a}[\mathrm{~B}]^{b}$

The $\Delta G^{o \prime}$ value is obtained from the $\Delta G^{o}$ value by making the appropriate corrections for $\mathrm{pH} 7$ (Thauer 
et al. 1977). $\Delta G_{\mathrm{f}}^{o}$ values for inorganics were taken from Stumm and Morgan (1996).

For example for the hydrogen driven reductive dehalogenation of chlorobenzene to benzene, that is for chlorobenzene $+\mathrm{H}_{2} \rightarrow$ benzene $+\mathrm{H}^{+}+\mathrm{Cl}^{-}$: $\Delta G^{o}=\Delta G_{\mathrm{f}}^{o}$ benzene $+\Delta G_{\mathrm{f}}^{o} \mathrm{H}^{+}+\Delta G_{\mathrm{f}}^{o} \mathrm{Cl}^{-}-\Delta G_{\mathrm{f}}^{o}$ chlorobenzene $-\Delta G_{\mathrm{f}}^{o} \mathrm{H}_{2}$ and $\Delta G^{\prime}=\Delta G^{o}+R T \ln$ $[$ benzene $]\left[\mathrm{H}^{+}\right]\left[\mathrm{Cl}^{-}\right] /[$chlorobenzene $]\left[\mathrm{H}_{2}\right]$

Speciation and $\mathrm{pH}$

Halophenols are weak acids, but stronger than phenol. In waste water weak acids are partially ionized and are in thermodynamic equilibrium with their conjugate bases. The notion that these species are in equilibrium implies that Gibbs free energy values for reactions where these compounds are reactants or products are calculated by using the $\Delta G_{\mathrm{f}}$ values of either the acid, with the formula

$\Delta G_{\mathrm{f}}=\Delta G_{\mathrm{f}}^{\mathrm{o}}+\mathrm{RT} \ln \alpha$

or the conjugated base with the formula

$\Delta G_{\mathrm{f}}=\Delta G_{\mathrm{f}}^{\mathrm{o}}+\mathrm{RT} \ln (1-\alpha)$

where $\alpha=10^{-\mathrm{pH}} /\left(10^{-\mathrm{pH}}+10^{-\mathrm{p} K \mathrm{a}}\right.$ ) (Dolfing et al. 2010). $\Delta G_{\mathrm{f}}$ values for halobenzoates were calculated after Dolfing and Harrison (1992) as

$\Delta G_{\mathrm{f}}$ halobenzoate $=\Delta G_{\mathrm{f}}$ halobenzoic acid

$$
+2.3 \mathrm{RTp} K_{\mathrm{a}}
$$

Gibbs free energies of chlorinated benzenes

Gibbs free energy of formation data for chlorinated benzenes in the aqueous phase (in $\mathrm{kcal} \mathrm{mol}^{-1}$ ) were taken from Sadowsky et al. (2013) and converted to $\mathrm{kJ} \mathrm{mol}^{-1}(1 \mathrm{kcal}=4.184 \mathrm{~kJ})$. These values were used to calculate the change in Gibbs free energy for the reductive dehalogenation reactions as described previously (Dolfing and Harrison 1992).

\section{Redox potentials}

Two electron reduction potentials were calculated after Thauer et al. (1977). For example: based on $G_{\mathrm{f}}^{o}$ values of -138.5 and $-133.5 \mathrm{~kJ} \mathrm{~mol}^{-1}$ for $\mathrm{C}_{6} \mathrm{Cl}_{6}$ and $\mathrm{C}_{6} \mathrm{Cl}_{5} \mathrm{H}$ respectively and values of 0 and -39.95 for $\mathrm{H}^{+}$at $\mathrm{pH} 0$ and $\mathrm{pH} 7$ respectively, and with $\Delta G_{\mathrm{f}} \mathrm{H}_{2}$ (gas) $=0 \mathrm{~kJ} \mathrm{~mol}^{-1} ; \Delta G_{\mathrm{f}} \mathrm{Cl}^{-}=-131.3 \mathrm{~kJ} \mathrm{~mol}^{-1}$ (Stumm and Morgan 1996) reductive dechlorination of hexachlorobenzene to pentachlorobenzene according to $\mathrm{C}_{6} \mathrm{Cl}_{6}+\mathrm{H}_{2}$ (gas) $\rightarrow \mathrm{C}_{6} \mathrm{Cl}_{5} \mathrm{H}+\mathrm{H}^{+}+\mathrm{Cl}^{-}$ yields $-126.3 \mathrm{~kJ} \mathrm{~mol}^{-1}$ under standard conditions (pH 0) and $-166.2 \mathrm{~kJ} \mathrm{~mol}^{-1}$ at $\mathrm{pH}$ 7. To calculate the corresponding redox potentials these values are then divided by $-\mathrm{nF} / 1,000,000$ where $n$ is the number of electrons transferred in the reaction and $F$ is the Faraday constant (96485 J/V) (Stumm and Morgan 1996) and $1,000,000$ is the multiplication factor to account for conversion of $\mathrm{kJ}$ to $\mathrm{mV}$ rather than $\mathrm{J}$ to $\mathrm{V}$. This would yield reduction potentials of 654 and $861 \mathrm{mV}$ for $\mathrm{pH} 0$ and $\mathrm{pH} 7$ respectively. For $\mathrm{pH} 7$ the latter value still needs to be corrected for the redox potential of the $\mathrm{H}^{+} / \mathrm{H}_{2}$ redox couple, which is $-414 \mathrm{mV}$ at $\mathrm{pH} 7$ (and indeed 0 at $\mathrm{pH}$ 0). Thus the redox potentials of the $\mathrm{C}_{6} \mathrm{Cl}_{6} / \mathrm{C}_{6} \mathrm{Cl}_{5} \mathrm{H}$ redox couple are $654 \mathrm{mV}$ at $\mathrm{pH} 0$ and $447 \mathrm{mV}$ at $\mathrm{pH} 7$ respectively.

\section{Results and discussion}

$\Delta G_{\mathrm{f}}^{\mathrm{o}}$ and $\Delta H_{\mathrm{f}}^{\mathrm{o}}$ values of chlorinated phenols

Quantum mechanical methods discriminate between conformers that are deemed to represent the same compound in the environment. For example, $\Delta G_{\mathrm{f}}^{\mathrm{o}}$ for syn-2-chlorophenol (2-chlorophenol) differs from $\Delta G_{\mathrm{f}}^{\mathrm{o}}$ for anti-2-chlorophenol (6-chlorophenol) (Supporting Information (SI) Table S1). This difference reflects the presence or absence of intramolecular hydrogen interaction ("bond") between hydroxyl hydrogen and the halogen. In environmental chemistry this distinction between conformers is not made, because in the environment each congener is present in the conformation that has the lowest energy. In the supporting material $\Delta G_{\mathrm{f}}^{\mathrm{o}}$ and $\Delta H_{\mathrm{f}}^{\mathrm{o}}$ values for all 31 chlorophenol congeners are provided. In Table 1 we present $\Delta G_{\mathrm{f}}^{\mathrm{o}}$ and $\Delta H_{\mathrm{f}}^{\mathrm{o}}$ values for the environmentally relevant congeners.

Table 1 shows the $\Delta H_{\mathrm{f}}^{\mathrm{o}}$ and $\Delta G_{\mathrm{f}}^{\mathrm{o}}$ values for all 19 environmentally relevant chlorophenols for both the gaseous and the aqueous phase. The $\Delta G_{\mathrm{f}}^{\mathrm{o}}$ values range between -75.7 and $-137.9 \mathrm{~kJ} / \mathrm{mol}$ for the gas phase and between -95.2 and $-144.3 \mathrm{~kJ} / \mathrm{mol}$ for the aqueous phase. These values are lower than those previously reported (Dolfing and Harrison 1992). There is considerable scatter in plots of the new versus these "old" data (Fig. 1). This is not surprising 
Table 1 Thermodynamic data for chlorinated phenols under standard conditions (in $\left.\mathrm{kJ} \mathrm{mol}^{-1}\right)^{\mathrm{a}}$
${ }^{a}$ Standard conditions are: $25{ }^{\circ} \mathrm{C} ; 100 \mathrm{kPa}$ (gas phase) or $1 \mathrm{M}$ (aqueous solution)

b Experimental values are from Linstrom and Mallard (2012)

\begin{tabular}{lccccc}
\hline & $\Delta H_{\mathrm{f} g a s}^{\mathrm{o}}$ & $\Delta G_{\mathrm{f} \text { gas }}^{\mathrm{o}}$ & $\Delta H_{\mathrm{faq}}^{\mathrm{o}}$ & $\Delta G_{\text {f aq }}^{\mathrm{o}}$ & $\Delta H_{\mathrm{fgas}(\mathrm{exp})}^{\mathrm{ob}}$ \\
\hline Phenol & -96.4 & -51.2 & -118.0 & -72.8 & -96.4 \\
2-chlorophenol & -132.8 & -83.7 & -143.9 & -95.2 & \\
3-chlorophenol & -126.3 & -77.8 & -148.4 & -99.9 & \\
4-chlorophenol & -124.2 & -75.7 & -147.0 & -98.6 & \\
2,3-dichlorophenol & -154.7 & -101.7 & -165.1 & -112.4 & -151.6 \\
2,4-dichlorophenol & -156.6 & -104.2 & -168.1 & -116.3 & -156.3 \\
2,5-dichlorophenol & -162.2 & -109.7 & -173.1 & -120.9 & -158.4 \\
2,6-dichlorophenol & -152.6 & -99.9 & -164.7 & -112.8 & -146.3 \\
3,4-dichlorophenol & -145.9 & -93.7 & -168.3 & -116.3 & -150.3 \\
3,5-dichlorophenol & -151.8 & -99.9 & -173.0 & -121.2 & -148.2 \\
2,3,4-trichlorophenol & -174.8 & -118.1 & -184.3 & -128.0 & \\
2,3,5-trichlorophenol & -179.6 & -123.3 & -188.5 & -132.3 & \\
2,3,6-trichlorophenol & -173.9 & -117.4 & -184.4 & -131.0 & \\
2,4,5-dichlorophenol & -177.3 & -121.1 & -187.6 & -131.8 & \\
2,4,6-trichlorophenol & -180.5 & -124.5 & -191.3 & -136.5 & \\
3,4,5-trichlorophenol & -167.2 & -11.2 & -188.1 & -132.0 & \\
2,3,4,5-tetrachlorophenol & -191.7 & -131.4 & -199.6 & -139.4 & \\
2,3,4,6-tetrachlorophenol & -192.4 & -132.2 & -200.5 & -140.0 & \\
2,3,5,6-tetrachlorophenol & -193.8 & -133.5 & -201.4 & -142.2 & \\
Pentachlorophenol & -202.5 & -137.9 & -207.9 & -144.3 & \\
\hline
\end{tabular}

since quantum mechanical methods incorporate interactions that are not taken into account by group contribution methods which rely on transferability and averaging of properties of a particular functional group. The correlations between $\Delta H_{\text {fgas }}^{\mathrm{o}}$ and $\Delta G_{\mathrm{fgas}}^{\mathrm{o}}$, and between $\Delta H_{\text {faq }}^{\mathrm{o}}$ and $\Delta G_{\mathrm{faq}}^{\mathrm{o}}$ (Fig. 2) are excellent, while the correlation between $\Delta G_{\text {f gas }}^{\text {o }}$ and $\Delta G_{\text {faq }}^{\text {o }}$ (Fig. 2) is less perfect, which reflects inter alia the influence of molecular structure on solvent solute interactions.

$\Delta G_{\mathrm{f}}^{\mathrm{o}}$ and $\Delta H_{\mathrm{f}}^{\mathrm{o}}$ values of brominated phenols

Table 2 shows the $\Delta H_{\mathrm{f}}^{\mathrm{o}}$ and $\Delta G_{\mathrm{f}}^{\mathrm{o}}$ values for all 19 environmentally relevant bromophenols for both the gas and the aqueous phase (the data for the full series of 31 congeners is provided in SI Table S2. The $\Delta G_{\mathrm{f}}^{\mathrm{o}}$ values range between -45.1 and $59.1 \mathrm{~kJ} / \mathrm{mol}$ for the gas phase and between -63.0 and $45.7 \mathrm{~kJ} / \mathrm{mol}$ for the aqueous phase. Contrary to the case for chlorophenols $\Delta G_{\mathrm{f}}^{\mathrm{o}}$ aq values for bromophenols decrease with increasing degree of halogenation (Fig. 3). Plots of $\Delta H_{\text {fgas }}^{\mathrm{o}}$ and $\Delta G_{\mathrm{f} \text { aq }}^{\mathrm{o}}$ values of chlorinated phenols versus those of bromophenols illustrate that the effect of chloro

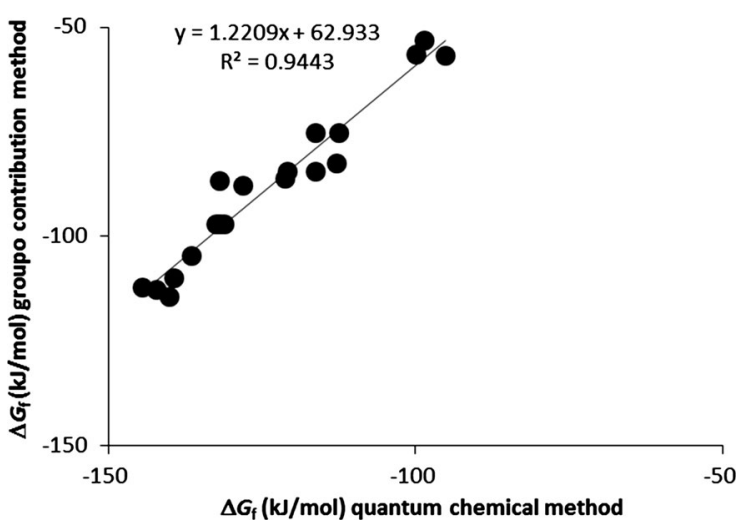

Fig. 1 Gibbs free energy of formation values of chlorinated phenols in the aqueous phase $\left(1 \mathrm{M} ; 25^{\circ} \mathrm{C}\right)$. Values obtained with a group contribution method are from Dolfing and Harrison (1992)

substituents on the stability of compound is fundamentally different from that of bromo substituents (Fig. 4). This is due to the fact that chlorine is a more electronegative element than bromine, and because bromine is a larger atom, which will introduce steric 
Fig. 2 Relationships between thermodynamic parameters of chlorophenols. a Relationship between $\Delta G_{\text {f gas }}^{\mathrm{o}}$ and $\Delta H_{\mathrm{fgas}}^{\mathrm{o}}$, b relationship between $\Delta G_{\mathrm{f} \text { aq }}^{\mathrm{o}}$ and $\Delta H_{\mathrm{f} \text { aq }}^{\mathrm{o}}$, and c relationship between $\Delta G_{\mathrm{f} \text { aq }}^{\mathrm{o}}$ and $\Delta G_{\mathrm{fgas}}^{\mathrm{o}}$

Table 2 Thermodynamic data for brominated phenols under standard conditions (in $\mathrm{kJ} \mathrm{mol}^{-1}$ )

a Standard conditions are: $25{ }^{\circ} \mathrm{C} ; 100 \mathrm{kPa}$ (gas phase) or $1 \mathrm{M}$ (aqueous solution)

b Experimental values are from Linstrom and Mallard (2012)
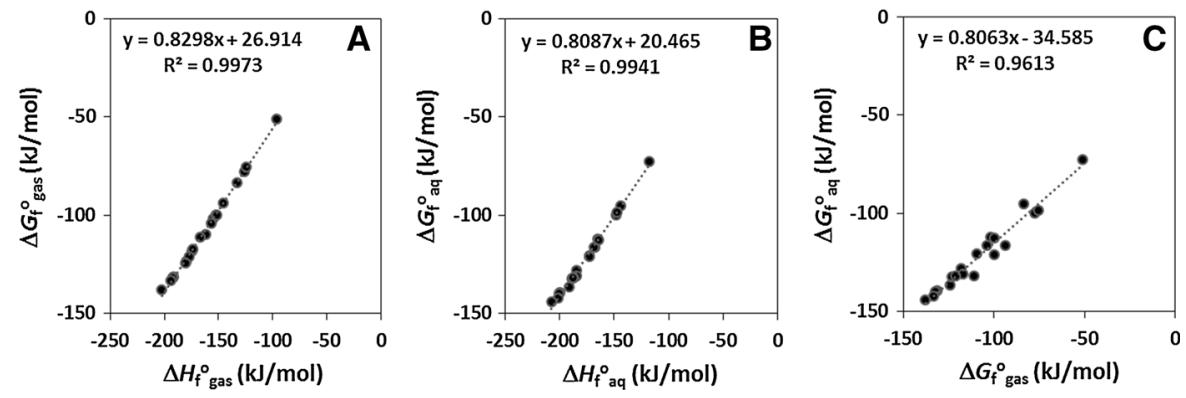

\begin{tabular}{|c|c|c|c|c|c|}
\hline & $\Delta H_{\text {fgas }}^{\mathrm{o}}$ & $\Delta G_{\text {fgas }}^{\mathrm{o}}$ & $\Delta H_{\mathrm{f} \text { aq }}^{\mathrm{o}}$ & $\Delta G_{\text {faq }}^{\mathrm{o}}$ & $\Delta H_{\text {fgas(exp) }}^{\text {ob }}$ \\
\hline Phenol & -96.4 & -51.2 & -118.0 & -72.8 & -96.4 \\
\hline 2-bromophenol & -79.9 & -45.1 & -91.8 & -57.3 & \\
\hline 3-bromophenol & -72.9 & -38.6 & -97.4 & -63.0 & \\
\hline 4-bromophenol & -71.0 & -37.0 & -96.0 & -62.0 & \\
\hline 2,3-dibromophenol & 48.7 & 24.3 & -62.0 & -37.9 & \\
\hline 2,4-dibromophenol & 52.5 & 28.7 & -66.9 & -43.6 & \\
\hline 2,5-dibromophenol & 53.7 & 29.9 & -67.3 & -43.3 & \\
\hline 2,6-dibromophenol & -49.0 & -24.9 & -60.6 & -37.6 & \\
\hline 3,4-dibromophenol & -39.4 & -15.8 & -65.6 & -42.0 & \\
\hline 3,5-dibromophenol & -46.7 & -23.5 & -72.1 & -49.0 & \\
\hline 2,3,4-tribromophenol & -13.3 & 0.1 & -42.5 & -29.7 & \\
\hline 2,3,5-tribromophenol & -21.2 & -7.7 & -34.6 & -21.2 & \\
\hline 2,3,6-tribromophenol & -16.3 & -2.7 & -27.9 & -15.4 & \\
\hline 2,4,5-tribromophenol & -18.9 & -5.6 & -34.0 & -21.6 & \\
\hline 2,4,6-tribromophenol & -19.8 & -6.9 & -30.9 & -19.6 & -0.9 \\
\hline 3,4,5-tribromophenol & -4.7 & 8.5 & -32.0 & -19.0 & \\
\hline 2,3,4,5-tetrabromophenol & 23.4 & 26.8 & 8.2 & 12.0 & \\
\hline 2,3,4,6-tetrabromophenol & 20.5 & 23.7 & 9.9 & 7.3 & \\
\hline 2,3,5,6-tetrabromophenol & 18.7 & 21.9 & 8.1 & 9.3 & \\
\hline Pentabromophenol & 65.6 & 59.1 & 54.8 & 45.7 & \\
\hline
\end{tabular}

repulsion (and hence destabilization) with neighboring substituents (be these substituents hydrogens, bromines or $\mathrm{OH}$ groups).

Reliability of calculated standard enthalpy of formation values of halophenols

The experimental standard enthalpies of formation in the gas phase for some halophenols and the parent phenol (Linstrom and Mallard 2012) were used to assess the reliability of our calculated values (Tables 1-2). We note that that agreement with experimental and calculated values for most chlorophenols is close to the stated uncertainty of $4 \mathrm{~kJ} / \mathrm{mol}$.
However, the discrepancy between calculated and experimental standard enthalpy for 2,4,6-tribromophenol (the only one for which $\Delta H_{\mathrm{f}}^{\mathrm{o}}$ had been reported) is much larger and suggests that the measured value (Linstrom and Mallard 2012) needs to be reassessed.

Halogenated phenols, speciation and $\mathrm{pH}$

$\mathrm{pH}$ affects the speciation of halophenols (Mun et al. 2008). Dissociation of a halophenol results in the formation of a halophenolate and hence a decrease in the concentration of the halophenol. The degree of dissociation depends on the $\mathrm{pH}$ and the $\mathrm{p} K_{a}$ value of 
the halophenol congener (Dolfing et al. 2010). Table 3 (chlorophenols) and SI Table 3 (bromophenols) list the $\Delta G_{\mathrm{f}}^{\mathrm{o}}$ values corrected for dissociation at $\mathrm{pH} 7$ for chlorophenols and bromophenols, illustrating that the effect of dissociation is not necessarily negligible. This has implications for the energetics of the dehalogenation reaction. The $\mathrm{p} K_{\mathrm{a}}$ increases with decreasing degree of halogenation; this implies that deprotonation has a stabilizing effect on highly halogenated compounds. Ortho halophenols are more acidic than meta and para halophenols because of the large inductive effect of the halogen on the vicinal hydroxyl group (Han et al. 2004). For the same reason the acidity of halophenols increases with the number of halogen substitutions (Table 3 and SI Table S3).

\section{Redox potentials of halogenated phenols}

With $\mathrm{H}_{2}$ as electron donor reductive dehalogenation of halophenols is an exergonic process. Under standard

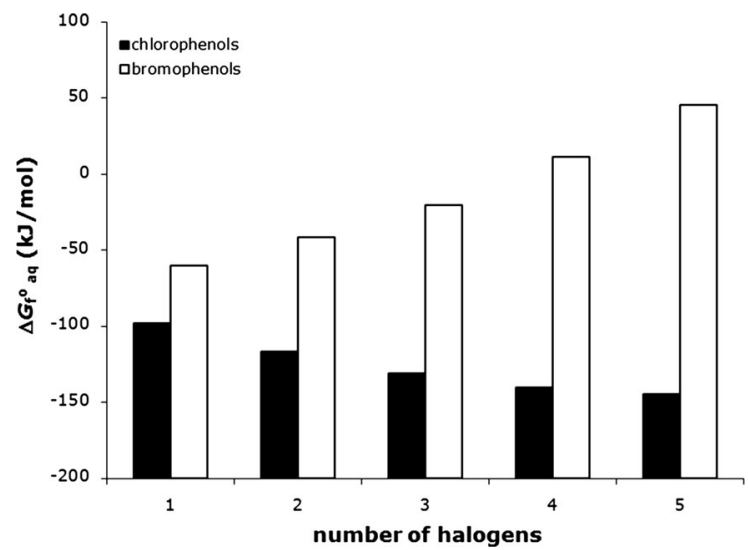

Fig. 3 Effect of the number of halogen substituents on the Gibbs free energy of formation of chloro- and bromophenols conditions the change in Gibbs free energy values for reductive dehalogenation of chlorophenols and bromophenols are in the range of -104 to $-129 \mathrm{~kJ}$ per mol chloride released and of -112 to $-146 \mathrm{~kJ}$ per mol bromide released respectively. At $\mathrm{pH} 7$ reductive dehalogenation is significantly more favorable than at

Table 3 Effect of $\mathrm{p} K_{a}$ on speciation and $\Delta G_{\mathrm{f} \text { aq }}^{\mathrm{o}}$ at $\mathrm{pH} 7$ for chlorophenols $^{\mathrm{a}}$

\begin{tabular}{lrrrr}
\hline & $\Delta G_{\text {faq }}^{\mathrm{o}}$ & $\mathrm{p} K_{a}$ & $\alpha^{\mathrm{b}}$ & $\Delta G_{\mathrm{f}}^{\mathrm{o}^{\prime} \mathrm{aq}}$ \\
\hline Phenol & -72.8 & 10.00 & 1.00 & -72.8 \\
2-chlorophenol & -95.2 & 8.46 & 0.97 & -95.3 \\
3-chlorophenol & -99.9 & 8.92 & 0.99 & -99.9 \\
4-chlorophenol & -98.6 & 9.13 & 0.99 & -98.6 \\
2,3-dichlorophenol & -112.4 & 7.90 & 0.89 & -112.7 \\
2,4-dichlorophenol & -116.3 & 7.94 & 0.90 & -116.5 \\
2,5-dichlorophenol & -120.9 & 7.35 & 0.69 & -121.8 \\
2,6-dichlorophenol & -112.8 & 6.49 & 0.24 & -116.3 \\
3,4-dichlorophenol & -116.3 & 8.43 & 0.96 & -116.4 \\
3,5-dichlorophenol & -121.2 & 7.87 & 0.88 & -121.5 \\
2,3,4-trichlorophenol & -128.0 & 7.53 & 0.77 & -128.7 \\
2,3,5-trichlorophenol & -132.3 & 6.79 & 0.38 & -134.7 \\
2,3,6-trichlorophenol & -131.0 & 5.65 & 0.04 & -138.8 \\
2,4,5-dichlorophenol & -131.8 & 6.90 & 0.44 & -133.8 \\
2,4,6-trichlorophenol & -136.5 & 5.78 & 0.06 & -143.6 \\
3,4,5-trichlorophenol & -132.0 & 7.39 & 0.71 & -132.8 \\
2,3,4,5-tetrachlorophenol & -139.4 & 6.63 & 0.30 & -142.4 \\
2,3,4,6-tetrachlorophenol & -140.0 & 5.11 & 0.01 & -150.8 \\
2,3,5,6-tetrachlorophenol & -142.2 & 5.05 & 0.01 & -153.3 \\
Pentachlorophenol & -144.3 & 4.84 & 0.01 & -156.7 \\
\hline a & & &
\end{tabular}

${ }^{\mathrm{a}} \mathrm{p} K_{a}$ values are taken from Han and Tao (2006); $\Delta G_{\mathrm{f} \text { aq }}^{\mathrm{o}}$ and $\Delta G_{\mathrm{f} \text { aq }}^{o \prime}$ are in $\mathrm{kJ} \mathrm{mol}^{-1}$

${ }^{b} \alpha$ is the fraction of chlorinated phenol present as chlorophenols; the fraction present as chlorophenolate is $1-\alpha$ c $\Delta G_{\mathrm{f}}^{\mathrm{o}}$ aq: $\Delta G_{\mathrm{f} \text { aq }}^{o \prime}$ at $\mathrm{pH} 7$
Fig. 4 Correlation between thermodynamic parameters of chlorophenols and bromophenols; a $\Delta H_{\text {f gas }}^{\text {o }}$, and $\mathbf{b} \Delta G_{\mathrm{f} \text { aq }}^{\mathrm{o}}$
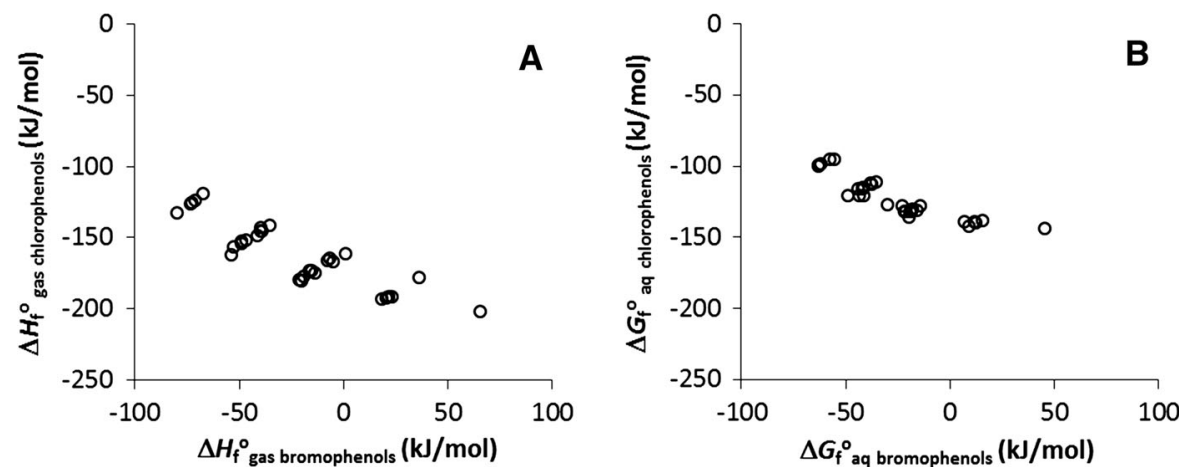
Table 4 Gibbs free energy values and redox potentials for the reductive dechlorination of chlorophenols with $\mathrm{H}_{2}$ (gas) as electron donor ${ }^{\mathrm{a}}$

\begin{tabular}{|c|c|c|c|c|c|}
\hline Reactant & Product & $\Delta G^{\mathrm{o}}$ & $\Delta G^{\mathrm{o}}$ & $E^{\mathrm{o}}$ & $E^{\mathrm{o} /}$ \\
\hline \multirow[t]{3}{*}{ Pentachlorophenol } & 2,3,4,5-tetrachlorophenol & -126.3 & -157.0 & 655 & 399 \\
\hline & 2,3,4,6-tetrachlorophenol & -127.0 & -165.4 & 658 & 443 \\
\hline & 2,3,5,6-tetrachlorophenol & -129.2 & -167.9 & 669 & 456 \\
\hline \multirow[t]{4}{*}{ 2,3,4,5-tetrachlorophenol } & 2,3,4-trichlorophenol & -120.0 & -157.6 & 622 & 402 \\
\hline & 2,3,5-trichlorophenol & -124.3 & -163.6 & 644 & 434 \\
\hline & 2,4,5-trichlorophenol & -123.7 & -162.7 & 641 & 429 \\
\hline & 3,4,5-trichlorophenol & -123.9 & -161.7 & 642 & 424 \\
\hline \multirow[t]{4}{*}{ 2,3,4,6-tetrachlorophenol } & 2,3,4-trichlorophenol & -119.3 & -149.1 & 618 & 358 \\
\hline & 2,3,6-trichlorophenol & -122.3 & -159.2 & 634 & 411 \\
\hline & 2,4,5-trichlorophenol & -123.0 & -154.2 & 638 & 385 \\
\hline & 2,4,6-trichlorophenol & -127.8 & -164.0 & 662 & 436 \\
\hline \multirow[t]{2}{*}{ 2,3,5,6-tetrachlorophenol } & 2,3,5-trichlorophenol & -121.5 & -152.7 & 629 & 377 \\
\hline & 2,3,6-trichlorophenol & -120.1 & -156.7 & 622 & 398 \\
\hline \multirow[t]{3}{*}{ 2,3,4-trichlorophenol } & 2,3-dichlorophenol & -115.7 & -155.3 & 599 & 391 \\
\hline & 2,4-dichlorophenol & -119.5 & -159.1 & 619 & 410 \\
\hline & 3,4-dichlorophenol & -119.6 & -159.0 & 619 & 410 \\
\hline \multirow[t]{3}{*}{ 2,3,5-trichlorophenol } & 2,3-dichlorophenol & -111.4 & -149.2 & 577 & 359 \\
\hline & 2,5-dichlorophenol & -119.9 & -158.4 & 621 & 407 \\
\hline & 3,5-dichlorophenol & -120.1 & -158.0 & 622 & 405 \\
\hline \multirow[t]{3}{*}{ 2,3,6-trichlorophenol } & 2,3-dichlorophenol & -112.7 & -145.1 & 584 & 338 \\
\hline & 2,5-dichlorophenol & -121.2 & -154.3 & 628 & 385 \\
\hline & 2,6-dichlorophenol & -113.1 & -148.8 & 586 & 357 \\
\hline \multirow[t]{3}{*}{ 2,4,5-trichlorophenol } & 2,4-dichlorophenol & -115.8 & -154.0 & 600 & 384 \\
\hline & 2,5-dichlorophenol & -120.4 & -159.3 & 624 & 411 \\
\hline & 3,4-dichlorophenol & -115.8 & -153.9 & 600 & 383 \\
\hline \multirow[t]{2}{*}{ 2,4,6-trichlorophenol } & 2,4-dichlorophenol & -111.1 & -144.2 & 575 & 333 \\
\hline & 2,6-dichlorophenol & -107.6 & -144.0 & 557 & 332 \\
\hline \multirow[t]{2}{*}{ 3,4,5-trichlorophenol } & 3,4-dichlorophenol & -115.6 & -154.8 & 599 & 388 \\
\hline & 3,5-dichlorophenol & -120.5 & -159.9 & 624 & 415 \\
\hline \multirow[t]{2}{*}{ 2,3-dichlorophenol } & 2-chlorophenol & -114.1 & -153.9 & 591 & 383 \\
\hline & 3-chlorophenol & -118.8 & -158.5 & 615 & 407 \\
\hline \multirow[t]{2}{*}{ 2,4-dichlorophenol } & 2-chlorophenol & -110.2 & -150.0 & 571 & 363 \\
\hline & 4-chlorophenol & -113.7 & -153.4 & 589 & 381 \\
\hline \multirow[t]{2}{*}{ 2,5-dichlorophenol } & 2-chlorophenol & -105.6 & -144.7 & 547 & 336 \\
\hline & 3-chlorophenol & -110.2 & -149.3 & 571 & 360 \\
\hline 2,6-dichlorophenol & 2-chlorophenol & -113.7 & -150.2 & 589 & 364 \\
\hline \multirow[t]{2}{*}{ 3,4-dichlorophenol } & 3-chlorophenol & -114.9 & -154.8 & 595 & 388 \\
\hline & 4-chlorophenol & -113.7 & -153.5 & 589 & 382 \\
\hline 3,5-dichlorophenol & 3-chlorophenol & -110.0 & -149.7 & 570 & 362 \\
\hline 2-chlorophenol & Phenol & -108.9 & -148.8 & 564 & 357 \\
\hline 3-chlorophenol & Phenol & -104.3 & -144.2 & 540 & 333 \\
\hline 4-chlorophenol & Phenol & -105.5 & -145.4 & 546 & 339 \\
\hline
\end{tabular}

electron reduction potentials naturally follow this drift (Table 4 for chlorophenols; SI Table S4 for bromophenols). A plot of the redox potentials of all redox 
couples for chlorinated phenols at $\mathrm{pH} 7$ versus the corresponding redox potentials under standard conditions illustrates that compared to $\mathrm{pH} 0 \mathrm{pH} 7$ especially favors meta and para dechlorination over ortho dechlorination (Fig. 5). A similar ortho effect was not observed for brominated phenols (data not shown).

\section{Redox potentials of chlorinated benzoates}

Chlorinated benzoates are the compounds with which Tiedje and co-workers made their seminal observations on microbial dehalogenation (Suflita et al. 1982). (Tang et al. 2010) recently used quantum chemical methods (at the G3XMP2 level) plus a polarizable conductor model to estimate Gibbs free energy of formation values of chlorinated benzoic acids for both the gas and the aqueous phase. At $\mathrm{pH} 7$ chlorinated benzoic acids are essentially fully deprotonated: their $\mathrm{p} K_{a}$ values range between -3.3 and 3.6 (Tang et al. 2010). Table 5 lists the Gibbs free energy values of all 19 chlorobenzoate congeners. A plot of these values versus those obtained with Benson's group contribution method (Dolfing and Harrison 1992) reveals a less than perfect correlation (Fig. 6a) indicating that analogous to the case for halophenols (Fig. 1) quantum chemical methods incorporate electronic interactions that are not taken into account by group contribution methods. The two electron reduction potentials for chlorobenzoic acids (Table 6) range between 560 and $707 \mathrm{mV}$. The redox potentials for chlorobenzoates at $\mathrm{pH} 7$ range between 285 and $501 \mathrm{mV}$. These values are systematically

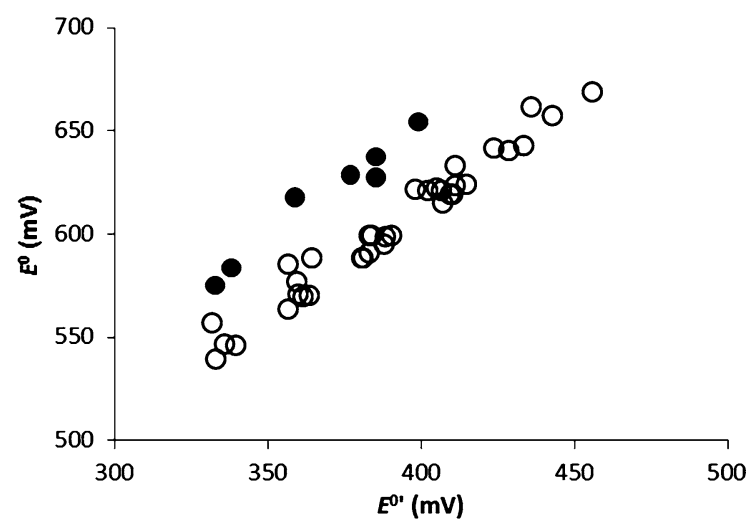

Fig. 5 Redox potentials for reductive dechlorination of chlorinated phenols under standard conditions $\left(E^{0}\right)$ versus the redox potentials for the same redox couple at $\mathrm{pH} 7\left(E^{0 \prime}\right)$. Black dots indicate redox couples representing ortho dechlorination of double ortho flanked hydroxyl groups different from those reported previously by Tang et al. (2010) who neglected to make the appropriate correction for the $\mathrm{H}^{+} / \mathrm{H}_{2}$ redox couple at $\mathrm{pH} 7$.

\section{Redox potentials of halogenated benzenes}

Sadowsky et al. (2013) recently used quantum chemical methods at the $6-311+\mathrm{G}(3 \mathrm{df}, 2 \mathrm{p})$ level plus the SMD implicit solvation model to estimate thermochemical properties of (poly)halobenzenes. A plot of the aqueous Gibbs free energy of formation values of chlorinated benzenes as obtained with Benson's group contribution method (Dolfing and Harrison 1992) versus the values obtained by Sadowsky et al. (2013) (Fig. 6b) shows a reasonably good correlation between the two approaches. A large part of the discrepancy between the two data sets appears due to the estimate for benzene itself, without any substituents. The scatter seems less than for the analogous comparison for chlorinated benzenes and benzoates (cf Fig. 1 and Fig. 6a), suggesting that one of the major weaknesses

Table $5 \Delta G_{\text {faq }}^{\mathrm{o}}\left(\right.$ in $\left.\mathrm{kJ} \mathrm{mol}^{-1}\right)$ for chlorobenzoates

\begin{tabular}{lcc}
\hline & $\begin{array}{l}\text { Benson's } \\
\text { method }^{\mathrm{a}}\end{array}$ & $\begin{array}{l}\text { Quantum } \\
\text { chemical }^{\text {method }}\end{array}$ \\
\hline 2-chlorobenzoate & -237.9 & -234.2 \\
3-chlorobenzoate & -246.0 & -246.5 \\
4-chlorobenzoate & -239.5 & -243.0 \\
2,3-dichlorobenzoate & -269.7 & -260.4 \\
2,4-dichlorobenzoate & -276.4 & -258.0 \\
2,5-dichlorobenzoate & -287.7 & -257.8 \\
2,6-dichlorobenzoate & -262.6 & -270.5 \\
3,4-dichlorobenzoate & -264.2 & -263.3 \\
3,5-dichlorobenzoate & -273.5 & -266.6 \\
2,3,4-trichlorobenzoate & & -273.4 \\
2,3,5-trichlorobenzoate & -293.4 & -280.7 \\
2,3,6-trichlorobenzoate & & -287.4 \\
2,4,5-dichlorobenzoate & & -271.0 \\
2,4,6-trichlorobenzoate & & -286.6 \\
3,4,5-trichlorobenzoate & & -276.1 \\
2,3,4,5-tetrachlorobenzoate & & -275.3 \\
2,3,4,6-tetrachlorobenzoate & & -296.8 \\
2,3,5,6-tetrachlorobenzoate & & -296.0 \\
Pentachlorobenzoate & & -299.6 \\
\hline 2 & & \\
\hline Values taken & & \\
\hline
\end{tabular}

a Values taken from Dolfing and Harrison (1992)

b Calculated from values in Tang et al. (2010) using Eq. 4 
Table 6 Gibbs free energy values and redox potentials for the reductive dechlorination of chlorobenzoic acids (at $\mathrm{pH} 0$ ) and chlorobenzoates (at $\mathrm{pH} 7$ ) with $\mathrm{H}_{2}$ (gas) as electron donor ${ }^{\mathrm{a}}$

\begin{tabular}{|c|c|c|c|c|c|}
\hline Reactant & Product & $\Delta G^{\mathrm{o}}$ & $\Delta G^{\mathrm{o} \prime}$ & $E^{\mathrm{o}}$ & $E^{\mathrm{O} \prime}$ \\
\hline \multirow[t]{3}{*}{ Pentachloro } & 2,3,4,5-tetrachloro & -129.6 & -146.8 & 672 & 347 \\
\hline & 2,3,4,6-tetrachlorol & -128.7 & -168.4 & 667 & 458 \\
\hline & 2,3,5,6-tetrachlorol & -126.9 & -167.5 & 658 & 454 \\
\hline \multirow[t]{4}{*}{ 2,3,4,5-tetrachloro } & 2,3,4-trichloro & -124.7 & -169.3 & 646 & 463 \\
\hline & 3,4,5-trichloro & -128.0 & -176.6 & 663 & 501 \\
\hline & 2,4,5-trichloro & -128.0 & -166.9 & 663 & 451 \\
\hline & 2,3,5-trichloro & -136.5 & -172.0 & 707 & 477 \\
\hline \multirow[t]{4}{*}{ 2,3,4,6-tetrachloro } & 2,3,4-trichloro & -125.6 & -147.7 & 651 & 352 \\
\hline & 2,3,6-trichloro & -124.7 & -161.7 & 646 & 424 \\
\hline & 2,4,5-trichloro & -128.9 & -145.3 & 668 & 339 \\
\hline & 2,4,6-trichloro & -126.2 & -160.9 & 654 & 420 \\
\hline \multirow[t]{2}{*}{ 2,3,5,6-tetrachloro } & 2,3,5-trichloro & -130.7 & -155.9 & 677 & 394 \\
\hline & 2,3,6-trichloro & -126.5 & -162.6 & 656 & 428 \\
\hline \multirow[t]{3}{*}{ 2,3,4-trichloro } & 2,3-dichloro & -121.5 & -158.1 & 630 & 405 \\
\hline & 2,4-dichloro & -125.1 & -155.8 & 648 & 393 \\
\hline & 3,4-dichloro & -135.5 & -161.1 & 702 & 421 \\
\hline \multirow[t]{3}{*}{ 2,3,5-trichloro } & 2,3-dichloro & -118.2 & -150.7 & 613 & 367 \\
\hline & 3,5-dichloro & -122.3 & -148.2 & 634 & 354 \\
\hline & 2,5-dichloro & -133.3 & -157.0 & 691 & 400 \\
\hline \multirow[t]{3}{*}{ 2,3,6-trichloro } & 2,3-dichloro & -122.4 & -144.1 & 634 & 333 \\
\hline & 2,6-dichloro & -126.5 & -141.5 & 656 & 319 \\
\hline & 2,5-dichloro & -119.9 & -154.2 & 621 & 385 \\
\hline \multirow[t]{3}{*}{ 2,4,5-trichloro } & 2,4-dichloro & -121.8 & -158.2 & 631 & 406 \\
\hline & 2,5-dichloro & -122.3 & -157.9 & 634 & 404 \\
\hline & 3,4-dichloro & -132.2 & -163.5 & 685 & 433 \\
\hline \multirow[t]{2}{*}{ 2,4,6-trichloro } & 2,4-dichloro & -124.5 & -142.6 & 645 & 325 \\
\hline & 2,6-dichloro & -118.4 & -155.0 & 614 & 389 \\
\hline \multirow[t]{2}{*}{ 3,4,5-trichloro } & 3,4-dichloro & -123.7 & -158.3 & 641 & 407 \\
\hline & 3,5-dichloro & -124.8 & -161.6 & 647 & 424 \\
\hline \multirow[t]{2}{*}{ 2,3-dichloro } & 2-chloro & -118.3 & -145.1 & 613 & 338 \\
\hline & 3-chloro & -131.9 & -157.4 & 684 & 401 \\
\hline \multirow[t]{2}{*}{ 2,4-dichloro } & 2-chloro & -114.7 & -147.4 & 594 & 350 \\
\hline & 4-chloro & -127.2 & -156.1 & 659 & 395 \\
\hline \multirow[t]{2}{*}{ 2,5-dichloro } & 2-chloro & -114.2 & -147.6 & 592 & 351 \\
\hline & 3-chloro & -127.8 & -159.9 & 662 & 415 \\
\hline 2,6-dichloro & 2-chloro & -120.8 & -135.0 & 626 & 285 \\
\hline \multirow[t]{2}{*}{ 3,4-dichloro } & 3-chloro & -117.9 & -154.4 & 611 & 386 \\
\hline & 4-chloro & -116.8 & -150.8 & 605 & 368 \\
\hline 3,5-dichloro & 3-chloro & -116.8 & -151.1 & 605 & 369 \\
\hline 2-chloro & Benzoic acid/benzoate & -121.6 & -154.1 & 630 & 385 \\
\hline 3-chloro & Benzoic acid/benzoate & -108.0 & -141.8 & 560 & 321 \\
\hline 4-chloro & Benzoic acid/benzoate & -109.1 & -145.4 & 565 & 339 \\
\hline
\end{tabular}

${ }^{\mathrm{a}}$ Standard conditions are $25{ }^{\circ} \mathrm{C}$; solutes at $1 \mathrm{M}, \mathrm{H}_{2}$ gas at $1 \mathrm{~atm} ; \Delta G^{\mathrm{o}}$ and $E^{\mathrm{o}}$ are for $\mathrm{pH} 0 ; \Delta G^{o \prime}$ and $E^{\mathrm{o} \prime}$ are for $\mathrm{pH} 7 . \Delta G$ values are in $\mathrm{kJ}_{\text {reaction }}{ }^{-1} ; E$ values are in $\mathrm{mV}$. Values are based on Tang et al. (2010) with corrections for $\mathrm{pH} 7$ calculated using Eq. 4 


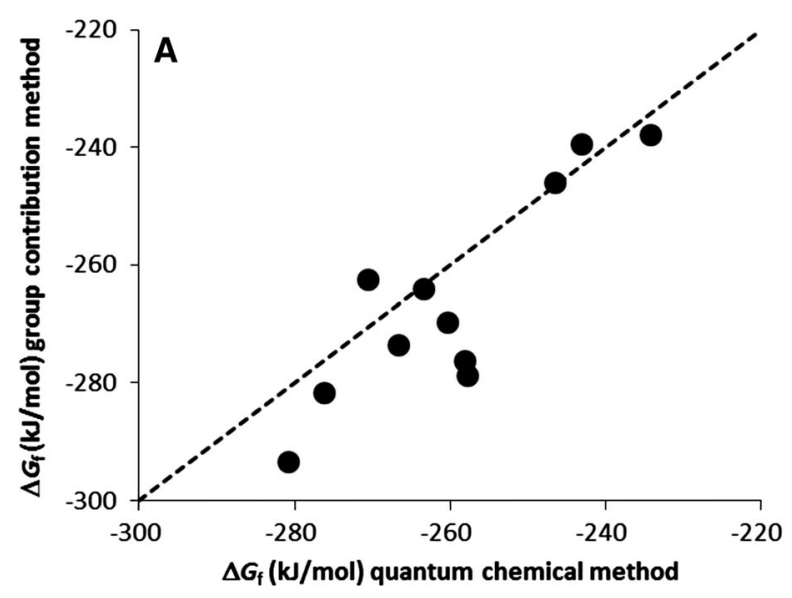

Fig. 6 Gibbs free energy of formation values of a chlorinated benzoates and $\mathbf{b}$ chlorinated benzenes in the aqueous phase $\left(1 \mathrm{M} ; 25^{\circ} \mathrm{C}\right)$. Values obtained with quantum chemical methods are based on Tang et al. (2010) and on Sadowsky et al. (2013)

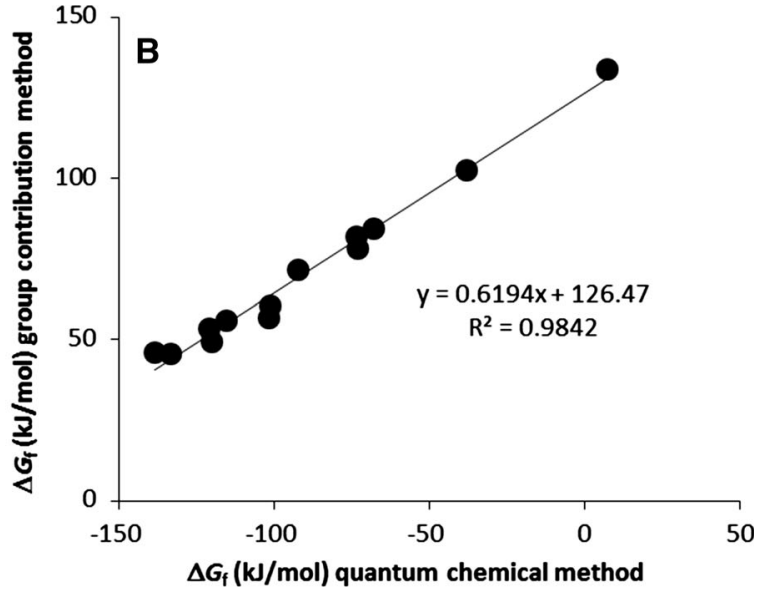

respectively; values obtained with group contribution methods are from Dolfing and Harrison (1992). The dotted line in a is the 1:1 line; a trendline in a (not shown) would have $R^{2}=0.76$
Table 7 Gibbs free energy values and redox potentials for the reductive dechlorination of chlorinated benzenes with $\mathrm{H}_{2}$ (gas) as electron donor ${ }^{\mathrm{a}}$

a Standard conditions are $25{ }^{\circ} \mathrm{C}$; solutes at $1 \mathrm{M}, \mathrm{H}_{2}$ gas at $1 \mathrm{~atm} ; \Delta G^{\mathrm{o}}$ and $E^{\mathrm{o}}$ are for $\mathrm{pH} 0 ; \Delta G^{o \prime}$ and $E^{\mathrm{o} \prime}$ are for $\mathrm{pH}$ 7. $\Delta G$ values are in $\mathrm{kJ}$ reaction ${ }^{-1} ; E$ values are in $\mathrm{mV}$. Values are based on Gibbs free energies in (Sadowsky et al. 2013); see Materials and methods for details

\begin{tabular}{|c|c|c|c|c|c|}
\hline Reactant & Product & $\Delta G^{0}$ & $\Delta G^{0^{\prime}}$ & $E^{0}$ & $E^{0^{\prime}}$ \\
\hline Hexachlorobenzene & Pentachlorobenzene & -126.3 & -166.2 & 654 & 447 \\
\hline \multirow[t]{3}{*}{ Pentachlorobenzene } & 1,2,3,4-tetrachlorobenzene & -113.3 & -153.3 & 587 & 380 \\
\hline & 1,2,3,5-tetrachlorobenzene & -117.9 & -157.9 & 611 & 404 \\
\hline & 1,2,4,5-tetrachlorobenzene & -118.7 & -158.7 & 615 & 408 \\
\hline \multirow[t]{2}{*}{ 1,2,3,4-tetrachlorobenzene } & 1,2,3-trichlorobenzene & -108.3 & -148.2 & 561 & 354 \\
\hline & 1,2,4-trichlorobenzene & -117.1 & -157.0 & 607 & 400 \\
\hline \multirow[t]{3}{*}{ 1,2,3,5-tetrachlorobenzene } & 1,2,3-trichlorobenzene & -103.7 & -143.6 & 537 & 330 \\
\hline & 1,3,5-trichlorobenzene & -112.9 & -152.8 & 585 & 378 \\
\hline & 1,2,4,-trichlorobenzene & -112.5 & -152.4 & 583 & 376 \\
\hline 1,2,4,5-tetrachlorobenzene & 1,2,4-trichlorobenzene & -111.6 & -151.6 & 579 & 372 \\
\hline \multirow[t]{2}{*}{ 1,2,3-trichlorobenzene } & 1,2-dichlorobenzene & -106.6 & -146.6 & 552 & 346 \\
\hline & 1,3-dichlorobenzene & -112.5 & -152.4 & 583 & 376 \\
\hline \multirow[t]{3}{*}{ 1,2,4-trichlorobenzene } & 1,2-dichlorobenzene & -97.8 & -137.8 & 507 & 300 \\
\hline & 1,3-dichlorobenzene & -103.7 & -143.6 & 537 & 330 \\
\hline & 1,4-dichlorobenzene & -103.3 & -143.2 & 535 & 328 \\
\hline 1,3,5-trichlorobenzene & 1,3-dichlorobenzene & -103.3 & -143.2 & 535 & 328 \\
\hline 1,2-dichlorobenzene & Monochlorobenzene & -101.6 & -141.5 & 526 & 320 \\
\hline 1,3-dichlorobenzene & Monochlorobenzene & -95.7 & -135.7 & 496 & 289 \\
\hline 1,4-dichlorobenzene & Monochlorobenzene & -96.2 & -136.1 & 498 & 291 \\
\hline Monochlorobenzene & Benzene & -86.1 & -126.1 & 446 & 239 \\
\hline
\end{tabular}

chlorobenzoates. The redox potentials for polyhalogenated benzenes range between 446 and $654 \mathrm{mV}$ at $\mathrm{pH} 0$ and between 239 and $447 \mathrm{mV}$ at $\mathrm{pH} 7$ respectively (Table 7). The latter values are considerably lower than those listed by Sadowsky et al. (2013). 


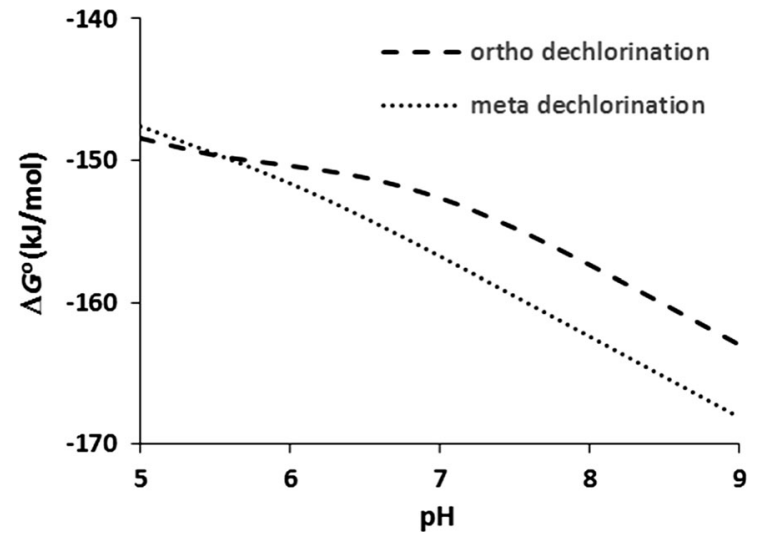

Fig. 7 Effect of $\mathrm{pH}$ on the change in Gibbs free energy for the reductive dechlorination of 2,3,5,6-tetrachlorophenol to 2,3,5and 2,3,6-trichlorophenol

Quantum chemical methods versus Benson's group contribution method

A comparison of Gibbs free energy of formation values and redox potentials for various classes of halogenated aromatics obtained with Benson's method versus datasets obtained with quantum chemical methods illustrates that quantum chemical methods allow a level of precision not achievable with group contribution methods. Not only was there a less than perfect agreement between the respective datasets for chlorobenzoates and chlorophenols there was also considerable scatter (Fig. 1 and Fig. 6a). Interestingly, this scatter was far less for the chlorinated benzenes (Fig. 6b). Thus it appears that the group contribution method did especially poor for interactions between the carboxy and the hydroxy group on the one hand and the chloro substituents on the other hand. Another interesting observation is that the consensus Gibbs free energy value for benzene in the aqueous phase in the $1990 \mathrm{~s}(32.0 \mathrm{kcal} / \mathrm{mol}$; $133.9 \mathrm{~kJ} / \mathrm{mol}$ ) (Shock and Helgeson 1990) was considerably higher than the value recently calculated by Sadowsky et al. (1.7 kcal/mol; $7.1 \mathrm{~kJ} / \mathrm{mol})$ (2013).

\section{Conclusions}

The present comprehensive state-of-the-art dataset of enthalpy and Gibbs free energy of formation values of all chlorinated and brominated phenols makes it possible to calculate change in Gibbs free energy values and redox potentials for reductive dehalogenation of halogenated phenols in the aqueous phase at temperatures other than the standard temperature of 298.15 K, something that was not possible with the previously published dataset, which lacked the required enthalpy values. Other improvements include the incorporation of brominated phenols in the data set, and data for the speciation of halogenated phenols at $\mathrm{pH}$ 7. The effect of $\mathrm{pH}$ on speciation noticed above may affect which dechlorination reaction is energetically most favorable. Figure 7 shows an example where dechlorination of 2,3,5,6-tetrachlorophenol at the ortho position is more favorable than dechlorination at the meta position at $\mathrm{pH} 5$ but not at $\mathrm{pH} 7$.

The data presented here illustrate that halogenated aromatics are excellent electron acceptors: the carbonhalogen bond represents a considerable source of energy. Developing technologies to harness the energy involved seems a worthwhile challenge, for example in microbial fuel cells (Huang et al. 2012). Microorganisms per se have already developed this ability (Leys et al. 2013). The classical example of microbial energy generation by organohalide respiration was with 3-chlorobenzoate as electron acceptor (Dolfing and Tiedje 1987; Dolfing 1990; Mohn and Tiedje 1990). Since then a wide variety of organohalide respiring bacteria have been identified, including organisms that can grow with halogenated benzenes, benzoates and phenols as electron acceptor (Hug et al. 2013). The present data can be used to calculate the amount of energy that is potentially available to these organisms under in situ conditions. Another potential use of the present data-set is in evaluating the dehalogenation pattern of polyhalogenated aromatics. It has been observed for various classes of halogenated compounds, including chlorophenols, that the change in Gibbs free energy values can be used to rationalize dechlorination patterns, with the energetically most favorable reactions the most likely to occur (Dolfing and Harrison 1993; Dolfing 1995, 2003), although here some restrictions apply: microorganisms and their metabolic machinery do not necessarily follow the thermodynamically predicted pathways, steric and other chemical factors may also play a role (Dolfing 2003). A case in point is the often demonstrated preferred microbial ortho-dehalogenation of chlorophenols (e.g. Adrian et al. 2003; Utkin et al. 1995), which is contrary to what would be expected if the 
organisms would preferentially use the thermodynamically most favorable pathway. Thus dehalogenation of chlorophenols by dehalogenases in Dehalococcoides strain DCB1 and 195 and Desulfitobacterium dehalogenans JW/IU-DC1 is under kinetic control, in contrast to dehalogenation of chlorophenols by vitamin $\mathrm{B}_{12 \mathrm{~s}}$ which appears to be under thermodynamic control. The latter conclusion was drawn in 1995 based on the thermodynamic data available at that time (Dolfing 1995) and still holds when the data presented in Table 4 are used for the evaluation.

Acknowledgments This study was supported by the Biotechnology and Biological Sciences Research Council UK (BB/K003240/2) and a Faculty Research Fellowship from Newcastle University. Parts of the results were presented at 246th National Meeting of the American Chemical Society in Indianapolis; constructive comments from the audience and three anonymous reviewers are gratefully acknowledged.

Open Access This article is distributed under the terms of the Creative Commons Attribution License which permits any use, distribution, and reproduction in any medium, provided the original author(s) and the source are credited.

\section{References}

Adrian L, Hansen SK, Fung JM, Görisch H, Zinder SH (2003) Growth of Dehalococcoides strains with chlorophenols as electron acceptors. Environ Sci Technol 41:2318-2323

Baboul AG, Curtiss LA, Redfern PC, Raghavachari K (1999) Gaussian-3 theory using density functional geometries and zero-point energies. J Chem Phys 110:7650-7657

Cox JD, Wagman DD, Medvedev VA (1989) CODATA key values for thermodynamics. Hemipshere Publishing, New York

Dolfing J (1990) Reductive dechlorination of 3-chlorobenzoate is coupled to ATP production and growth in an anaerobic bacterium, strain DCB-1. Arch Microbiol 153:264-266

Dolfing J (1995) Regiospecificity of chlorophenol reductive dechlorination by vitamin $\mathrm{B}_{12 \mathrm{~s}}$. Appl Environ Microbiol 61:2450-2451

Dolfing J (2003) Thermodynamic considerations for dehalogenation. In: Häggblom MM, Bossert ID (eds) Dehalogenation: Microbial processes and environmental applications. Kluwer, Boston, pp 89-114

Dolfing J, Harrison BK (1992) The Gibbs free energy of formation of halogenated aromatic compounds and their potential role as electron acceptors in anaerobic environments. Environ Sci Technol 26:2213-2218

Dolfing J, Harrison BK (1993) Redox and reduction parameters to predict the degradation pathway of chlorinated benzenes in anaerobic environments. FEMS Microbiol Ecol 13:23-30

Dolfing J, Tiedje JM (1987) Growth yield increase linked to reductive dechlorination in a defined 3-chlorobenzoate degrading methanogenic coculture. Arch Microbiol 149:102-105

Dolfing J, Xu A, Head IM (2010) Anomalous energy yields in thermodynamic calculations: importance of accounting for $\mathrm{pH}$-dependent organic acid speciation. ISME J 4:463-464

Farai M, de Vos WM, Smidt H (2010) Exploiting the ecogenomics toolbox for environmental diagnostics of organohalide-respiring bacteria. Trends Biotechnol 28:308-316

Field JA, Sierra-Alvarez R (2008) Microbial degradation of chlorinated phenols. Rev Environ Sci Bio/Technol 7:211-241

Frisch MJ, Trucks GW, Schlegel HB, Scuseria GE, Robb MA, Cheeseman JR, Zakrzewski VG, Montgomery JA Jr, Stratmann RE, Burant JC, Dapprich S, Millam JM, Daniels AD, Kudin KN, Strain MC, Farkas O, Tomasi J, Barone V, Cossi M, Cammi R, Mennucci B, Pomelli C, Adamo C, Clifford S, Ochterski J, Petersson GA, Ayala PY, Cui Q, Morokuma K, Malick DK, Rabuck AD, Raghavachari K, Foresman JB, Cioslowski J, Ortiz JV, Stefanov BB, Liu G, Liashenko A, Piskorz P, Komaromi I, Gomperts R, Martin RL, Fox DJ, Keith T, Al-Laham MA, Peng CY, Nanayakkara A, Gonzalez C, Challacombe M, Gill PMW, Johnson B, Chen W, Wong MW, Andres JL, Gonzalez C, Head-Gordon M, Replogle ES, Pople JA (2003) Gaussian 03, Revision E1. Gaussian Inc., Pittsburgh, PA, USA

Han J, Tao F-M (2006) Correlations and predictions of pKa values of fluorophenols and bromophenols using hydrogen-bonded complexes with ammonia. J Phys Chem A 110:257-263

Han J, Deming RL, Tao F-M (2004) Theoretical study of molecular structures and properties of the complete series of chlorophenols. J Phys Chem A 108:7736-7743

Heidrich ES, Curtis TP, Dolfing J (2011) Determination of the internal chemical energy of wastewater. Environ Sci Technol 45:827-832

Huang L, Chai X, Quan X, Logan BE, Chen G (2012) Reductive dechlorination and mineralization of pentachlorophenol in biocathode microbial fuel cells. Bioresour Technol 111:167-174

Huang L, Shi Y, Wang N, Dong Y (2014) Anaerobic/aerobic conditions and biostimulationfor enhanced chlorophenols degradation in biocathode microbial fuel cells. Biodegradation. doi:10.1007/s10532-014-9686-1

Hug LA, Maphosa F, Leys D, Löffler FE, Smidt H, Edwards EA, Adrian L (2013) Overview of organohalide-respiring bacteria and a proposal for a classification system for reductive dehalogenases. Phil Trans R Soc B 368:20120322

Leys D, Adrian L, Smidt H (2013) Organohalide respiration: microbes breathing chlorinated molcecules. Phil Trans R Soc B Biol Sci 368:20120316

Linstrom PJ, Mallard WG (2012) NIST Chemistry WebBook, NIST Standard Reference Database Number 69. National Institute of Standards and Technology, Gaithersburg http:// webbook.nist.gov. Accessed 09 Apr 2014

Marenich AV, Cramer CJ, Truhlar DG (2009) Universal solvation model based on solute electron density and a continuum model of the solvent defined by the bulk dielectric constant and atomic surface tensions. J Phys Chem B 113:6378-6396

McCarty PL (1997) Breathing with chlorinated solvents. Science 276:1521-1522 
Mohn WW, Tiedje JM (1990) Strain DCB-1 conserves energy for growth from reductive dechlorination coupled to formate oxidation. Arch Microbiol 153:267-271

Mun $\mathrm{CH}, \mathrm{Ng}$ WJ, He J (2008) Acidogenic sequencing batch reactor start-up procedures for induction of 2,4,6-trichlorophenol dechlorination. Water Res 42:1675-1683

Novak I (2004) Ab initio vs molecular mechanics thermochemistry: homocubanes. J Chem Inf Comp Sci 44(3): 903-906

Sadowsky D, McNeill K, Cramer CJ (2013) Thermochemical factors affecting the dehalogenation of aromatics. Environ Sci Technol 47:14194-14203

Shock EL, Helgeson HC (1990) Calculation of the thermodynamic and transport properties of aqueous species at high pressures and temperatures: standard partial molal properties of organic species. Geochim Cosmochim Acta 54:915-945

Strycharz SM, Gannon SM, Boles AR, Nevin KP, Franks AE, Lovley DR (2010) Reductive dechlorination of 2-chlorophenol by Anaeromyxobacter dehalogenans with an electrode serving as the electron donor. Environ Microbiol Rep 2:289-294

Stumm W, Morgan JJ (1996) Aquatic Chemistry, 3rd edn. Wiley, New York

Suflita JM, Horowitz A, Sheldon DR, Tiedje JM (1982) Dehalogenation - a novel pathway for the anaerobic biodegradation of haloaromatic compounds. Science 218: 1115-1117

Tang A, Wang L, Zhou R (2010) Gibbs energies of formation of chlorinated benzoic acids and benzoates and application to their reductive dechlorination. J Mol Struct (THEOCHEM) 960:31-39

Thauer RK, Jungermann K, Decker K (1977) Energy conservation in chemotrophic anaerobic bacteria. Bacteriol Rev 41:100-180

Utkin I, Dalton DD, Wiegel J (1995) Specificity of reductive dehalogenation of substituted ortho-chlorophenols by Desulfitobacterium dehalogenans JW/IU-DC1. Appl Environ Microbiol 61:346-351 